\title{
Skenaariotyöskentelyllä tietoa tulevaisuuden sosiaali- ja terveyspalveluista ja osaamistarpeista
}

Annikki Jauhiainen ${ }^{1}$, TtT, yliopettaja, projektipäällikkö; Päivi Sihvo ${ }^{2}$, THM, lehtori, projektipäällikkö; Heli Jääskeläinen $^{3}$, sairaanhoitaja-terveydenhoitaja (AMK), kehittäjäsairaanhoitaja; Juuso Ojasalo ${ }^{2}$, YtM, projektiasiantuntija; Susanne Hämäläinen ${ }^{1}$, TtM, lehtori, terveydenhuollon asiantuntija

${ }^{1}$ Savonia-ammattikorkeakoulu, lisalmi, Finland; 2 Karelia-ammattikorkeakoulu, Joensuu, Finland; ${ }^{3}$ Siun Sote, Pohjois-Karjalan sosiaali- ja terveyspalvelujen kuntayhtymä, Joensuu, Finland

Annikki Jauhiainen, Savonia-ammattikorkeakoulu, PL 72, FI-74101 lisalmi, FINLAND. Sähköposti: annikki.jauhiainen@savonia.fi

\section{Tiivistelmä}

Kahden kehittämishankkeen tavoitteena oli tuottaa tietoa sosiaali- ja terveydenhuollon digitaalisista tulevaisuuksista ja tulevaisuudessa tarvittavasta osaamisesta. Tiedonhankinta toteutettiin skenaariotyöskentelynä tulevaisuustyöpajoissa. Työpajoihin osallistui yhteensä 73 henkilöä. Osallistujat työskentelivät sosiaali- ja terveydenhuollossa julkisella ja yksityisellä sektorilla, ICT-yrityksissä, koulutusorganisaatioissa sekä kolmannella sektorilla, mukana oli myös kansalaisia. Työpajoissa hyödynnettiin myös etäyhteyttä ja aineisto koottiin sähköisille ilmoitustauluille.

Työpajoissa tuotettiin yhteensä 25 skenaariota, joista löytyi kahdeksan erilaista teemaa: tiedonhallinta, biohakkerointi, etäpalvelut, robotiikka - suorittavan työn automatisointi, moniammatillisuus, digiarkkitehtuuri, asiakaslähtöisyys ja asiakkaan vastuu sekä inhimillinen kohtaaminen. Tulevaisuuden osaaminen muodostui kymmenestä osaamisalueesta, jotka edelleen luokiteltiin kolmeen laajempaan luokkaan: sosiaali- ja terveydenhuollon ammattilaisen perusosaaminen, sosiaali- ja terveydenhuollon ammattilaisen erikoisosaaminen, teknologian ja sosiaali- ja terveydenhuollon ammattilaisen yhteinen osaaminen. Sosiaali- ja terveydenhuollon ammattilaisen erikoisosaamiseen sisältyy myös tietojärjestelmien ja ohjelmistojen kehittämisosaaminen.

Skenaariotyöskentelyllä saatiin alustavaa tietoa tulevaisuuden sosiaali- ja terveyspalveluista ja osaamistarpeista. Tätä tietoutta käytetään kehittämishankkeissa digitaalisten palvelujen kehittämisessä sekä laajemmin koulutussuunnittelussa. Tulevaisuustyöpajoissa saatiin tietoa myös skenaariotyöskentelystä ja sen soveltuvuudesta kehittämistoiminnalle.

Avainsanat: tulevaisuudentutkimus, työpajat, skenaariot, osaaminen, digitalisaatio, kehittämisprojektit 


\section{Abstract}

The aim of the two development projects was to provide information about the future of digital social- and health care and the necessary future competencies. Data acquisition was carried out by scenario work in the future workshops. The workshops were attended total of 73 people. The participants worked in the social and health care, both in the public and private sectors, in ICT companies, in educational organizations, and in the third sector. Among the participants were also ordinary citizens. The workshops were remotely connected and data was collected into electronic bulletin boards.

The workshops produced total of 25 scenarios, which found eight different themes: information management, quantified self, remote services, robotics - automation of manual labour, multiprofessionality, digital architecture, customer-oriented services and the customer's responsibility, and human encounter.

Future competency consisted of ten areas of expertise, which classified into three broader categories: basic knowhow of social and health care professionals, special know-how of social and health care professionals and the collective know-how of social and health care and technology professionals. The special know-how also includes information systems and software development skills.

Scenario work provided preliminary information about the future social and health services and qualifications. This information will be used in further development projects of digital services as well as more widely in education planning. The future workshops provided information about the scenario method and its compatibility with development activities.

Keywords: forecasting, workshops, trends, health care, telemedicine, professional competence

\section{Johdanto}

Teknologinen kehitys ja digitalisaatio muuttavat suomalaista yhteiskuntaa nopeasti. Yhteiskunnan digitalisaatio rikkoo organisaatiorajoja ja muuttaa toimintatapoja sekä edellyttää asiakaslähtöistä uusien palvelujen ja palvelumuotojen synnyttämistä julkisen ja yksityisen sektorin toimijoiden yhteistyönä [1]. Sosiaali- ja terveydenhuollon palvelujen kehittämistarvetta edellyttää digitalisaation lisäksi myös meneillään oleva sosiaali- ja terveydenhuollon rakenneuudistus. Kansalaisilla on käytettävissä sekä virallisia kansallisia ja alueellisia sähköisiä palveluja että vapaasti käytössä olevia palveluja. Palvelujen digitalisaatiossa on kyse siitä, että digitaalisilla työkaluilla ja ympäristöillä on mielekäs rooli palvelun tuottamisessa [2]. Palvelujen kehittämisen kannalta on tarve hahmottaa tulevaisuudessa tarvittavia palveluita ja sitä, miten digitalisaatio tulee muuttamaan niitä ja mitä haasteita nämä tuovat henkilöstön ja asiakkaiden osaamisen kehittämiselle.
Tulevaisuuden sosiaali- ja terveydenhuollon palvelujen muutosta on ennakoitu erilaisissa skenaarioissa ja megatrendeissä [3-8]. Näissä tulevaisuutta tarkastellaan laajasti huomioiden yhteiskunnalliset ja globaalit ilmiöt sekä digitalisaation nopea kehitys, joilla on osaltaan vaikutusta kansalaisten hyvinvointiin sekä sosiaali- ja terveydenhuollon palveluihin ja työhön. Skenaario on Meristön [9] mukaan oletuksiin perustuva tulevaisuudenkuva, joka kokonaisvaltaisesti ja moniulotteisesti luonnostelee tulevaisuuden toimintaa ja toimintaympäristöä sekä kuvaa kehityspolkua nykyisyydestä tulevaisuuteen. Skenaariot ilmentävät myös erilaisia arvoja ja periaatteita [10]. Skenaariotyöskentelyn menetelmin voidaan tehokkaasti arvioida digitalisaation ja erilaisten kehitysvaihtoehtojen vaikutuksia yhteiskunnan tai oman organisaation toimintaan ja mahdollisuuksiin. Skenaariota voidaankin käyttää tulevaisuuden pohdinnan ja suunnittelun sekä toimintamallien ja strategioiden työkaluna. [11] Skenaariotyöskentelyllä hahmottuneiden tulevaisuuskuvien perusteella luodaan 
visio siitä, mitä yhteiskunnassa tai organisaatiossa tavoitellaan [10].

\section{Sosiaali- ja terveydenhuollon palvelujen tulevaisuu- denkuvia}

Digitalisaatio on vaikuttanut sosiaali- ja terveydenhuolIon hallintoon, työhön ja palveluihin jo nyt ja tulee tulevaisuudessa muuttamaan niitä entistä enemmän ja monipuolisemmin [3]. Linturin [4] mukaan nopeasti kehittyviä teknologioita ovat olleet muun muassa rutiinimainen kattava DNA-luenta, tauteja, fysiologisia tiloja ja organismien ominaisuuksia nopeasti tunnistavat biosirut tai biosensorit sekä henkilökohtaiset oman kehon analysaattorit.

Sosiaali- ja terveydenhuollon palvelujen tulevaisuutta on visioitu eri tahojen toteuttamana. Sitra [5] on esittänyt kestävää hyvinvointia tavoittelevan vision, jossa suomalaiset elävät hyvää ja merkityksellistä elämää maapallon kantokyvyn rajoissa. Se tarkoittaa sitä, että hyvinvointiin tartutaan kokonaisvaltaisesti ja maapallon kantokykyyn sopeudutaan. Tehy [6] on päätynyt osallistavan ennakoinnin ja suunnittelun lopputuloksena esittämään kahdeksan tulevaisuuden megatrendiä, jotka ovat matka ubiikkiyhteiskuntaan, terveys ja hyvinvointi, maailman väestön ikääntyminen, tietosuhteen muutos, globalisaatio, teknologian kehitys, sosio-kulttuurinen muutos sekä eettis-ekologinen muutos. Aaltonen ja Vauramo [3] ovat tarkastelleet sosiaali- ja terveysalan tulevaisuutta pitkällä 25 vuoden aikajänteellä. He esittävät uutta ajattelua organisoinnin, talouden ja digitalisaation näkökulmista. Tulevaisuuden pohdinnasta nousevat erityisesti esille päätöksenteon arvopohjan merkitys, paikallisen tason merkityksen nousu, uusi taloudellinen ajattelu sekä digitaalisen alustan synty.

Sitra esittää vuosittain trendilistan globaalien muutosilmiöiden suunnasta. Vuonna 2016 esitettiin kolme megatrendiä: teknologia muuttaa kaiken (keinoäly, kaiken instrumentointi, robotisaatio, bioteknologia ja farmakologia), globaali arkinen ja jännitteinen keskinäisriippuvuus sekä kestävyyskriisi [7]. Trendeistä 'teknologia muuttaa kaiken' vaikuttaa selkeimmin tulevaisuuden sosiaali- ja terveyspalveluihin. Trendit ovat kuitenkin sidoksissa toisiinsa [7]. Pelkästään teknologioihin liittyvää visiointia on tehnyt Linturi [8]. Hän kuvaa kymmenen uuden sosioteknisen innovaation hyötyjä, uhkia ja toimenpiteitä, joilla voi olla laaja vaikutus ihmisten arkeen ja työelämään. Näistä sosiaali- ja terveydenhuoltoa koskettavat erityisesti yksilöllinen lähivalmistus, sote-hakkerointi, lisätty todellisuus ja IoT (Internet of Things), etiäis- ja palvelurobotiikka sekä oppimisen digitalisaatio. Linturin [8] mukaan yhteiskunnassa tulisi pohtia, miten teknologian tuottamiin uusiin mahdollisuuksiin suhtaudutaan. Joka tapauksessa luodessaan uusia mahdollisuuksia ja riskejä teknologinen kehitys muuttaa arvomaailmaa.

\section{Tulevaisuuden osaaminen}

Palvelujen digitalisaatio edellyttää toimintatapojen muutosta ja palveluketjujen uudistamista. Tiedonhallinnan muutokset muuttavat työtä, toimintoja ja tietoa [12]. Digitalisaation aiheuttama muutos työn tekemisessä edellyttää uudenlaista osaamista. Osaamistarpeita ennakoimalla saadaan tietoa, millaista osaamista työelämässä tarvitaan tulevaisuudessa. Opetushallituksen ennakointiraporttien mukaan eri aloja yhdistävät muutostekijät ovat tuomassa muutoksia tulevaisuuden palveluihin, tuotteisiin, työnkuviin, työnjakoon ja työuriin. Näitä muutostekijöitä ovat esimerkiksi kansainvälistyminen, moniammatillisuus ja -alaisuus, palvelukulttuurin muutos sekä digitalisaation ja yleisen teknologisen kehityksen ja älyratkaisuiden korostuminen. Näiden muutostekijöiden mukaisesti tulevaisuuden osaamisessa korostuvat voimakkaasti tieto- ja viestintäteknologiaan liittyvä osaaminen ja medialukutaito. Digitalisaatio edellyttää erityisesti asiakaslähtöisyyden ja asiakassegmentoinin tarpeita sekä innovaatioosaamista, mutta myös kokonaisuuksien hallintaa ja kykyä moniammatilliseen yhteistyöhön. Viestinnällisiä taitoja tarvitaan myös laajasti. [13]

Digitalisaation myötä osaamisalueeksi on noussut digiosaaminen tai digitaalinen kompetenssi. Digiosaaminen ei koostu pelkästään teknisistä taidoista. Mattila [14] määrittelee digitaalista osaamista tieto- ja viestintätekniikan perustaitojen lisäksi syvällisemmällä osaamisella, joka sisältää kyvyn vastata monimutkaisiin 
haasteisiin hyödyntäen psykologisia resursseja. Ferrarin [15] mukaan digitaalinen kompetenssi muodostuu tiedoista, taidoista ja asenteista, joita vaaditaan tieto- ja viestintäteknologiaa ja digitaalista mediaa käytettäessä. Digitaalinen kompetenssi koostuu seitsemästä osaalueesta, jotka ovat tiedonhallinta, yhteistyö ja osallistuminen verkoissa, keskustelu ja tiedon jakaminen, tiedon ja sisällön tuottaminen, eettisyys ja vastuullisuus, arviointi ja ongelmanratkaisu, tekniset taidot käyttää teknologiaa ja sosiaalista mediaa. Laine [16] jakaa digitalisaation vaatiman osaamisen kolmeen alueeseen eli yleisiin valmiuksiin ja asenteisiin, niin sanottuihin metataitoihin, perusosaamiseen ja erityisosaamiseen. Yleiset valmiudet sisältävät muutoskyvyn, vuorovaikutustaidot sekä ymmärryksen ihmisten erilaisista digitalisaatiovalmiuksista. Perusosaaminen koostuu digitaalisten palveluiden ja työvälineiden käyttötaidoista, perusymmärryksestä digitalisaation vaikutuksista asiakkaisiin, toimintaan ja omiin työtehtäviin, sekä verkostoitumisesta ja yhteistyöstä. Erityisosaamista tarvitsee osa ammattilaisista. Erityisosaaminen on kehittämisosaamista kuten asiakaskokemuksen kehittämistä, digitaalista markkinointia, laadun varmistamista sekö uusien kehittämismenetelmien hallintaa.

Aiemmassa kehittämishankkeessa selvitettiin sähköisten palvelujen käyttöönottoon ja käyttöön terveydenhuollossa tarvittavaa osaamista. Tässä osaamistarkastelussa osan osaamisalueista ja -vaatimuksista todettiin olevan erikoisosaamista, jota vain osa ammattilaisista tarvitsee. Osaamisvaatimuksia ryhmiteltiin kolmelle tasolle eli aloittelevan ammattilaisen, kokeneen ammattilaisen ja kehittäjä-ammattilaisen tasolle. [17]

Tässä artikkelissa kuvataan kahden kehittämishankkeen, Pohjois-Karjalan ja Pohjois-Savon DigiSote -hankkeiden [18-19] yhteistyönä toteuttamaa skenaariotyöskentelyä eli tulevaisuuden tarkastelua tulevaisuustyöpajoissa sekä työskentelyn tuloksia.

\section{Kehittämistyön tarkoitus, tavoitteet ja tehtävät}

Kehittämistyön tarkoituksena oli hahmotella tulevaisuuden sosiaali- ja terveydenhuollon palveluja digitalisaation näkökulmasta ja kuvata, millaista osaamista tulevaisuudessa tarvitaan. Tietoa tarvitaan PohjoisKarjalan ja Pohjois-Savon DigiSote -hankkeiden sosiaalija terveyspalveluiden digitalisaation suunnittelussa ja kokeiluissa sekä henkilöstön ja asiakkaiden osaamisen kehittämisessä. Hankkeissa tiedon avulla kehitetään myös tulevaisuuden eAmmattilaisen osaamisen kehittymispolkua ja valmennustuotteita. Tietoa tulevaisuudessa tarvittavasta osaamisesta tarvitaan laajemminkin, sillä sosiaali- ja terveydenhuollon muutoksessa on tarve kehittää sosiaali- ja terveydenhuollon ammattilaisten perus- ja täydennyskoulutuksia.

Tiedon tuottamisen lisäksi tavoitteena oli innostaa ja sitouttaa osallistujia sosiaali- ja terveyspalvelujen moniammatilliseen innovointiin ja kehittämistyöhön. Tavoitteena oli myös saada tietoa hanketoimijoille tulevaisuustyöpajoissa käytetystä skenaariomenetelmästä.

\section{Kehittämistehtävät olivat:}

1) Hahmotella sosiaali- ja terveydenhuollon digitaalisia tulevaisuuskuvia eli skenaarioita kehittämistyön perustaksi.

2) Kuvata tulevaisuuden sosiaali- ja terveydenhuollossa tarvittavaa osaamista.

\section{Menetelmät}

Skenaariotyöskentelyssä on käytettävissä monenlaisia menetelmiä. Tulevaisuustyöpaja on kansalaistoimintaa tukeva menetelmä [11]. Pohjois-Karjalan ja PohjoisSavon DigiSote -hankkeiden [18-19] tavoitteena on tuottaa uutta tietoa sosiaali- ja terveydenhuollon digitaalisista tulevaisuuksista, ja sitä kautta tunnistaa tulevaisuuden eAmmattilaisuus ja siihen liittyvä osaaminen. Tulevaisuustyöpajojen tarkoituksena uuden tiedon lisäksi oli saattaa yhteen yksityisiä palvelun tarjoajia sekä ICT- ja hoiva-alalta että julkiselta puolelta mukaan lukien päättäjät.

DigiSote-hankkeissa toteutetaan erilaisia digikokeiluja maakuntien alueella julkisella, yksityisellä ja kolmannella sektorilla. Hankkeiden ensimmäinen digikokeilu oli työpajojen järjestäminen eri paikkakunnilla samanaikaisesti etäyhteyden avulla. Ensimmäinen työpaja järjes- 
tettiin kuitenkin ilman etäyhteyttä varmistaen samalla työpajametodin toimivuus. Kyseiseen työpajaan osallistui 20 osanottajaa. Osanottajat olivat ICT-yrityksistä, julkisesta sosiaali- ja terveydenhuollosta, sosiaali- terveyden alan yrityksistä, kolmannelta sektorilta sekä oppilaitoksista. Toinen työpaja järjestettiin samanaikaisesti kahdella eri paikkakunnalla. Osallistujia oli yhteensä 53. Mukana oli myös palvelujen käyttäjiä eli kansalaisia. (Taulukko 1.)

Tulevaisuustyöpajat toteutettiin tulevaisuuden muistelu -menetelmän avulla. Asiantuntija johdatteli puheenvuorossaan osallistujat sosiaali- ja terveydenhuollon tulevaisuuteen eri näkökulmista. Tätä pajan vaihetta voidaan kutsua tietoiskuksi osallistujille niin, että heidän kiinnostuksensa aiheeseen herää tapausesimerkin avulla [20]. Tulevaisuuden muistelu eli ennakointidialogi on ratkaisukeskeinen kehittämistyökalu, jossa keskitytään tulevaisuuteen ja sen lähtökohtana ovat tulevaisuuteen suuntaavat kysymykset, jotka toimivat keskustelun pohjana. Tulevaisuutta on tarkoitus kuvata mahdollisimman konkreettisesti ja monimuotoisesti tavoitteena koota yhteen kuvaus asioista, joita eri toimijat ja ryhmät tulevat tekemään halutun tulevaisuuden saavuttami- seksi. [21] Menetelmän periaate on kelata kertomus kaukaisemmasta tulevaisuudesta kohti nykyhetkeä lähtökohdan ollessa kerronnallinen, kuvaileva ja dialoginen. Dialogin aikana jokainen ryhmän jäsen saa mahdollisuuden pohtia näkemyksiään, kuulla toisten ajatuksia teemasta ja niihin johtavasta toiminnasta sekä olemassa olevista hyvistä käytännöistä, ajankohtaisista huolista ja niiden vähentämisestä. Dialogin pohjalta syntyy yhteisen toiminnan suunnittelua. Menetelmä mahdollistaa näkemyseroavaisuuksien paikantamisen ja niihin ratkaisun hakemisen. [22]

Varsinainen työpajatyöskentely tapahtui ennalta määrätyissä pienryhmissä, joihin osallistujat oli jaettu edustamansa roolin mukaisesti. Tällä haluttiin tukea eri aloilta tulevien ammattilaisten kohtaamista ja vuoropuhelua sosiaali- ja terveydenhuollon mahdollisista tulevaisuuden näkymistä. Osallistujia pyydettiin pohtimaan hetki itsenäisesti sitä, miltä sosiaali- ja terveydenhuollon palvelujärjestelmä näyttäisi asiakkaan ja palvelujen tarjoajan näkökulmista vuonna 2040. Tulevaisuuden tarkastelu riittävän pitkällä aikavälillä on tarpeen, jotta tulevia muutoksia ja niiden seurauksia on helpompi ymmärtää [3].

Taulukko 1. Tulevaisuustyöpajoihin osallistujien lukumäärä ja taustaorganisaatiot.

\begin{tabular}{lcccc}
\hline Osallistujien taustaorganisaatio & $\begin{array}{c}\text { Työpaja 1/ } \\
\text { Pohjois-Karjala }\end{array}$ & $\begin{array}{c}\text { Työpaja 2/ } \\
\text { Pohjois-Karjala }\end{array}$ & $\begin{array}{c}\text { Työpaja 2/ } \\
\text { Pohjois-Savo }\end{array}$ & $\begin{array}{l}\text { Yhteensä } \\
\text { osallistujia }\end{array}$ \\
\hline Julkinen sosiaali- ja terveydenhuolto & 5 & 3 & 23 & 31 \\
Hoiva-alan yritys & 2 & 4 & & 6 \\
ICT-yritys & 6 & & 6 \\
Kolmas sektori & 2 & 3 & 10 & 5 \\
Oppilaitos & 5 & 3 & 2 & 18 \\
Muut hankkeet & & & 5 & 2 \\
Kansalaiset & & & 40 & 73 \\
Yhteensä osallistujia & 20 & 13 & & 5 \\
\hline
\end{tabular}


Itsenäisen pohdinnan jälkeen osallistujia pyydettiin jakamaan ajatuksiaan pienryhmässä. Pienryhmien tuli muodostaa sähköiselle Padlet-ilmoitustaululle tulevaisuuden skenaario vuodelle 2040 parilla lauseella perustuen ajatusten vaihtoon. Seuraavana tehtävänä osallistujia pyydettiin hahmottelemaan minkälaisia tekoja ja osaamista muodostetun skenaarion saavuttaminen vaatii nyt ja tulevaisuudessa. Lopulta pienryhmiä yhdisteltiin ja pyydettiin kahta ryhmää jakamaan tuotoksensa keskenään ja muodostamaan uusi yhteinen skenaario ja skenaarioon johtavat teot ja osaamiset sähköiselle Padlet-ilmoitustaululle. Nämä yhteiset skenaariot esiteltiin koko osallistujajoukolle ja niiden herättämistä ajatuksista keskusteltiin yhteisesti. Osallistujille annettiin mahdollisuus vielä työpajojen jälkeen kommentoida omien ja muiden ryhmien tuotoksia Padletilmoitustauluille.

Työpajoissa Padlet-ilmoitustaululle tuotettu materiaali ja skenaariot koottiin yhteen. Skenaariot analysoitiin etsimällä sisällöistä nousevia keskeisiä teemoja. Osaamista kuvaava aineisto analysoitiin induktiivisella sisällön analyysillä pelkistämällä, ryhmittelemällä ja luokittelemalla aineisto eritasoisiin kategorioihin [23]. Skenaarioiden ja osaamista kuvaavan aineiston lisäksi työpajatyöskentely tuotti laajan aineiston skenaarioihin johtavasta toiminnasta.

\section{Tulokset}

\section{Sosiaali- ja terveydenhuollon digitaaliset tulevaisuudet}

Tulevaisuustyöpajoissa ryhmät muotoilivat sosiaali- ja terveydenhuollon digitaalisista tulevaisuuksista yhteensä 25 skenaariota. Skenaarioiden sisällöistä analysoitiin kahdeksan erilaista teemaa. Jokaisesta skenaarioista löytyi 1-4 teemaa. Taulukossa 2 kuvataan eri teemojen esiintyminen skenaarioissa.

Skenaariot olivat esimerkiksi seuraavia:

Väestö pärjää kotona, robotiikka ja digitalisaatio palvelevat ennalta ehkäisevässä roolissa sekä ovat tehokkaasti käytössä sairauksien hoidossa, asumispalveluissa sekä kuntoutuksessa. Väestö seuraa hyvinvointiaan ja terveyttään itsenäisesti ja yksilöllisesti digitekniikan avulla. Tämän kaiken varmistaa käyttövarma ja luotettava digi-infrastruktuuri.

Palvelut ja asiantuntijuus ovat asiakkaille ja työntekijöille helposti saatavilla erilaisien virtuaalisten palvelujen avulla. Virtuaalisiin palveluihin suhtaudutaan myönteisesti ja niitä voidaan hyödyntää valtakunnallisesti. Suurinta osaa palvelusta voidaan käyttää virka-ajan ulkopuolella esim. videoidut ohjaukset. Palvelut ovat asiakaslähtöisiä ja näkökulmana ennaltaehkäisy.

Tiedonhallinta ja etäpalvelut -teemat esiintyivät useimmiten eri skenaarioissa, kumpikin teema esiintyi 13 eri skenaariossa. Tiedonhallintaa kuvattiin skenaarioissa esimerkiksi, että asiakkaan omat seurantatiedot siirtyvät tietokantaan, kaikki tarvittava tieto on turvallisessa verkkopalvelussa ja käytettävissä niin asiakkaalla kuin palveluntarjoajallakin missä päin maailmaa tahansa. Etäpalvelun teemaa edustivat näkemykset, että palvelujen ja avun saanti helpottuvat ja nopeutuvat erilaisten virtuaalisten palvelujen, sensorien ja älylaitteiden avulla. Tulevaisuudessa toimivat ja järkevät digitaaliset sovellukset mahdollistavat asiakkaan hyvinvointia paikasta riippumatta, väestö pärjää kotona robotiikka ja digitaaliset ratkaisut ovat ennalta ehkäisevässä roolissa, sairauksien hoidossa, asumispalveluissa ja kuntoutuksessa.

Biohakkerointi eli itsensä mittaaminen (Quantified Self) tuotiin esille 10 skenaariossa. Väestön nähtiin seuraavan hyvinvointiaan ja terveyttään itsenäisesti ja yksilöllisesti erilaisen seuranta- ja sensoritekniikan avulla. Sensoritekniikkaan liittyy tulevaisuudessa keinoäly, joka analysoi tietoa ja tekee diagnooseja. Biohakkerointiin liittyvän tekniikan nähtiin mahdollistavan kokonaisvaltaista ja yksilöllistä hoitoa ja auttavan kohdentamaan hoitajien resursseja esimerkiksi inhimilliseen kohtaamiseen ja tehtäviin, joissa tarvitaan hoitajan läsnäoloa. 
Taulukko 2. Eri teemojen esiintyminen skenaarioissa (f).

\begin{tabular}{lc}
\hline Skenaarioiden teemat & Teeman esiintyminen eri skenaarioissa \\
\hline Tiedonhallinta & 13 \\
Biohakkerointi & 10 \\
Etäpalvelut & 13 \\
Robotiikka - suorittavan työn automatisointi & 9 \\
Moniammatillisuus & 5 \\
Digiarkkitehtuuri & 4 \\
Asiakaslähtöisyys ja asiakkaan vastuu & 9 \\
Inhimillinen kohtaaminen & 3 \\
\hline
\end{tabular}

Robotiikka ja digitaaliset laitteet - suorittavan työn automatisointi -teemaan sisältyi robotiikan ja erilaisten digitaalisten laitteiden ja sovellusten käyttöä helpottamaan sosiaali- ja terveydenhuollossa suoritettavaa työtä. Tämä teema esiintyi yhdeksässä skenaariossa. Rutiinitehtävien vähentymisen nähtiin tehostavan työtä ja kohottavan työn laatua. Robotiikan ja seurantatekniikan lisäksi tuotiin esille muuta teknologiaa, kuten lisätyn todellisuuden teknologia (AR-lasit ja hologrammit) sekä keinoäly tiedon analysoinnissa. Digiarkkitehtuurin nähtiin varmistavan palvelujen saatavuutta.

Tiedonhallinnan, biohakkeroinnin, etäpalvelujen sekä robotiikan ja digitaalisten laitteiden - suorittavan työn automatisoinnin teeman mukaisia asioita löytyi tästä skenaarion osasta:

Teknologian kehitys tuo terveyden ja hyvinvoinnin seurannan ihmisen arkielämään mukaan. Oman elämän Big Data valjastetaan jokaisen ihmisen käyttöön. Henkilökohtaiset terveystiedot siirtyvät suoraan tietokantaan, joka on terveyspalveluiden ja henkilöiden omassa käytössä. Tekoäly käyttää tietokannassa olevaa dataa analysoimaan yksityishenkilöiden ja kansakunnan terveystilaa.

Moniammatillisuus ja asiantuntijuus tulivat esille viidessä skenaarioissa. Virtuaalisten palvelujen nähtiin hel- pottavan asiantuntijatiedon saatavuutta ja edistävän moniammatillista toimintaa. Asiakaslähtöisyyden ja asiakkaan vastuun sekä inhimillisen kohtaamisen teemat löytyivät myös skenaarioista. Palvelujen asiakaslähtöisyys, asiakkaan päätöksenteko ja omaa vastuu hoidosta tulivat esille. Inhimillinen kohtaaminen ja vuorovaikutus nähtiin myös tärkeänä osana etäpalvelujen lisäksi. Näitä kahta teemaa kuvaa ilmaisu eräässä skenaariossa:

Ihminen on itse oman hyvinvointinsa keskiössä ja hänellä on työkalut edistää omaa terveyttään ja välittävä yhteisö ympärillään.

\section{Tulevaisuuden sosiaali- ja terveydenhuollossa tarvitta- va osaaminen}

Työpajatyöskentelyn mukaan tulevaisuudessa tarvittava osaaminen voidaan jakaa neljään yläkategoriaan ja 10 alakategoriaan. Yläkategoriat ovat sosiaali- ja terveydenhuollon ammattilaisen perusosaaminen, sosiaali- ja terveydenhuollon ammattilaisen erikoisosaaminen, teknologian ja sosiaali- ja terveysalan ammattilaisten yhteinen osaaminen sekä teknologian ammattilaisen perusosaaminen, joka on samalla sosiaali- ja terveydenhuollon ammattilaisen erikoisosaamista. (Taulukko 3.) 
Taulukko 3. Tulevaisuuden sosiaali- ja terveydenhuollossa tarvittava osaaminen.

\begin{tabular}{|c|c|c|}
\hline Osaamisvaatimukset & \multicolumn{2}{|c|}{ Osaaminen } \\
\hline $\begin{array}{l}\text { Teknologian peruskäytön hallinta } \\
\text { Tietoturva- ja verkkoteknologiaosaaminen } \\
\text { Media- ja digitaalinen osaaminen } \\
\text { Ohjelmien kokonaisvaltainen osaaminen ja kattava käyttö }\end{array}$ & $\begin{array}{l}\text { Teknologinen osaami- } \\
\text { nen }\end{array}$ & $\begin{array}{l}\text { Sosiaali- ja terveyden- } \\
\text { huollon ammattilaisen } \\
\text { perusosaaminen }\end{array}$ \\
\hline $\begin{array}{l}\text { Tiedonhakutaidot } \\
\text { Kirjaamisosaaminen } \\
\text { Asiakkaalta kerättävän tiedon tulkinta ja hyödyntäminen } \\
\text { käytännössä } \\
\text { Palveluprosessien kokonaisuuden hallinta ja kuvaaminen }\end{array}$ & $\begin{array}{l}\text { Tiedonhallintaosaami- } \\
\text { nen }\end{array}$ & \\
\hline $\begin{array}{l}\text { Tietoisuus sähköisistä palveluista ja työkaluista } \\
\text { Sähköisten palvelujen käytön osaaminen } \\
\text { Parhaan mahdollisen tiedon ja osaamisen soveltaminen } \\
\text { Asiakaslähtöinen työskentelytapa } \\
\text { Eettisyysosaaminen digitaalisissa palveluissa }\end{array}$ & $\begin{array}{l}\text { Asiakaslähtöinen pal- } \\
\text { veluosaaminen }\end{array}$ & \\
\hline $\begin{array}{l}\text { Ihmisten kohtaaminen ja kuuntelu } \\
\text { Aidon kohtaamisen - dialogisuuden osaaminen } \\
\text { Empatiaosaaminen } \\
\text { Vuorovaikutus kasvokkain ja verkossa } \\
\text { Inhimillisyys ja asiakaslähtöisyys } \\
\text { Heittäytyminen asiakkaan näkökulmaan } \\
\text { Itseilmaisun taidot }\end{array}$ & $\begin{array}{l}\text { Vuorovaikutus- ja } \\
\text { verkkoviestintäosaa- } \\
\text { minen }\end{array}$ & \\
\hline $\begin{array}{l}\text { Avoimuus asiakkaan motivointiin } \\
\text { Asiakkaan motivointi- ja ohjaustaidot } \\
\text { Erilaisten ohjausmenetelmien hallinta }\end{array}$ & Ohjausosaaminen & \\
\hline $\begin{array}{l}\text { Avarakatseisuus ja innostuneisuus } \\
\text { Uskallus ylittää rajoja } \\
\text { Epävarmuuden sieto } \\
\text { Avoimuus ja myönteinen ajattelu uusien asioiden oppimi- } \\
\text { seen } \\
\text { Rohkeus kehittyä ja kokeilla }\end{array}$ & $\begin{array}{l}\text { Myönteinen asenne } \\
\text { uuden oppimiseen ja } \\
\text { kehittämiseen }\end{array}$ & \\
\hline $\begin{array}{l}\text { Muutosjohtamisen osaaminen } \\
\text { Johtamisosaaminen } \\
\text { Projektijohtamisen osaaminen } \\
\text { Verkostoitumistaidot } \\
\text { Markkinointiosaaminen } \\
\text { Rahoitusosaaminen } \\
\text { Yrittäjyysosaaminen } \\
\text { Juridiikkaosaaminen }\end{array}$ & $\begin{array}{l}\text { Johtamis- ja yrittä- } \\
\text { jyysosaaminen }\end{array}$ & $\begin{array}{l}\text { Sosiaali- ja terveyden- } \\
\text { huollon ammattilaisen } \\
\text { erikoisosaaminen }\end{array}$ \\
\hline Ks. teknologian ammattilaisen osaamisvaatimukset & $\begin{array}{l}\text { Tietojärjestelmien ja } \\
\text { ohjelmistojen kehittä- } \\
\text { misosaaminen }\end{array}$ & \\
\hline Moniammatillinen työtapa & Monialainen yhteis- & Teknologian ja sosiaali- \\
\hline
\end{tabular}




\begin{tabular}{|l|l|l|}
\hline $\begin{array}{l}\text { Yhteistyökykyisyys ja verkostoituminen } \\
\text { Yhteistyö eri alojen asiantuntijoiden kanssa } \\
\text { Eri alojen ammattilaisten yhteisen kielen hallinta }\end{array}$ & työosaaminen & $\begin{array}{l}\text { ja terveydenhuollon } \\
\text { ammattilaisen yhteinen } \\
\text { osaaminen }\end{array}$ \\
\hline $\begin{array}{l}\text { Ohjelmistojen kehittämistarpeen/tuotekehityksen tunnis- } \\
\text { taminen }\end{array}$ & $\begin{array}{l}\text { Tietojärjestelmien ja } \\
\text { ohjelmistojen kehittä- } \\
\text { Ymisosaaminen }\end{array}$ & $\begin{array}{l}\text { Teknologian ammattilai- } \\
\text { sen perusosaaminen }\end{array}$ \\
$\begin{array}{l}\text { Käyttöliittymäsuunnittelu ja ohjelmointitaito } \\
\text { Yhteentoimivuusstandardien tunteminen } \\
\text { Tietojärjestelmien käytettävyys ja kehittäminen } \\
\text { Käyttäjälähtöinen vaatimusmäärittely } \\
\text { Ohjelmistokehityksen johtamisosaaminen } \\
\text { Palvelin- ja verkkotekniikkaan liittyvä osaaminen }\end{array}$ & \\
& & \\
\end{tabular}

Sosiaali- ja terveydenhuollon ammattilaisen perusosaaminen koostuu kuudesta osaamisalueesta, jotka ovat teknologinen osaaminen, tiedonhallintaosaaminen, asiakaslähtöinen palveluosaaminen, vuorovaikutus- ja verkkoviestintäosaaminen, ohjausosaaminen sekä myönteinen asenne uuden oppimiseen ja kehittämiseen sekä elinikäisen oppimisen taidot. Teknologisen osaamisen osaamisvaatimuksina nähtiin teknologian perusvalmiuksien ja tietoturva- ja verkkoteknologiaosaamisen lisäksi media- ja digitaalinen osaaminen sekä ohjelmien kokonaisvaltainen osaaminen ja kattava käyttö. Tiedonhallintaosaaminen sisältää myös asiakkailta kerättävän tiedon tulkinnan ja hyödyntämisen sekä palveluprosessien kokonaisuuden hallinnan ja taidot kuvata palveluprosessi. Asiakaslähtöistä palveluosaamista kuvaavia osaamisvaatimuksia ovat tietoisuus sähköisistä palveluista ja työkaluista, sähköisten palvelujen käytön osaaminen, parhaan mahdollisen tiedon ja osaamisen soveltaminen, asiakaslähtöinen työskentelytapa sekä eettisyysosaaminen digitaalisissa palveluissa. Vuorovaikutus- ja verkkoviestintäosaamisen osaamisvaatimuksissa korostuvat asiakkaan kohtaamisen ja itseilmaisun taidot erilaisissa vuorovaikutustilanteissa kasvokkain ja verkossa. Samoin ohjausosaaminen edellyttää erilaisten ohjausmenetelmien hallintaa. Perusosaamiseen sisältyi myös myönteinen asenne uuden oppimiseen ja kehittämiseen sekä elinikäinen oppiminen. Näissä osaamisvaatimuksina tuli esille muun muassa rohkeus kehittyä ja kokeilla sekä ammattitaidon jatkuva päivittäminen, myös kielitaito ja kansainvälisyysosaaminen liitettiin osaamisvaatimuksiin. (Taulukko 3.)
Sosiaali- ja terveydenhuollon ammattilaisen erikoisosaamista on johtamis- ja yrittäjyysosaaminen, joka sisältää esimerkiksi ennakoivan ja muutosjohtamisen sekä projektijohtamisen osaamisen, markkinointi-, rahoitus- ja yrittäjyysosaamisen. Sosiaali- ja terveydenhuollon ammattilaisen erikoisosaamista ja samalla teknologian ammattilaisen perusosaamista on tietojärjestelmien ja ohjelmistojen kehittämisosaaminen. Tämä osaamisalue sisältää muun muassa ohjelmistojen kehittämistarpeen/tuotekehityksen tunnistamisen, ymmärryksen robotiikan ja keinoälyn mahdollisuuksista sekä käyttöliittymäsuunnittelun ja ohjelmointitaidon. Lisäksi kaikkien ammattilaisten yhteistä osaamista on monialainen yhteistyöosaaminen, joka koostuu moniammatillisesta työtavasta, yhteistyökykyisyydestä ja verkostoitumisesta sekä yhteistyöstä eri alojen asiantuntijoiden kanssa. Myös eri alojen ammattilaisten yhteisen kielen hallinta nähtiin osaamisvaatimuksena monialaisessa yhteistyöosaamisessa. (Taulukko 3.)

\section{Pohdinta}

Tulevaisuustyöpajoissa tuotettiin skenaarioita, tulevaisuudenkuvia sosiaali- ja terveyspalveluista ja niissä tarvittavia osaamisalueita ja -vaatimuksia. Skenaarioista johdetaan kokeiluaihioita, joita käytetään kehittämishankkeissa tulevaisuuden palvelujen suunnittelussa ja kokeiluissa [ks. 11]. Skenaarioissa tuli esille aiemmissa skenaarioissa ja megatrendeissä esitettyjä tulevaisuuskuvia ja teknologioita kuten Linturin [8] esittämät bio- 
hakkerointi, robotiikka, keinoäly sekä lisätty todellisuus. Digiarkkitehtuurin nähtiin tehostavan palvelujen saatavuutta. Aaltonen ja Vauramo [3] painottivat digitaalisen alustan merkitystä digitaalisten palvelujen mahdollisuuksille ja globaaleille ominaisuuksille. Uudistuva teknologia muuttaa sosiaali- ja terveyspalveluja laajasti, mikä muuttaa myös arvomaailmaa [8] ja edellyttää arvokeskustelua [3]. Etäpalvelujen lisääntymisen nähtiin helpottavan hoitoa ja avunsaantia. Etäpalveluihin liitettiin asiakkaan osallisuus ja vastuu omasta hoidostaan esimerkiksi itsemittaamisen avulla. Asiakaslähtöisyys, asiakkaan päätöksenteko ja inhimillinen kohtaaminen sisältyi myös skenaarioihin. Näitä asioita on painotettu myös Sote-tieto hyötykäyttöön -strategiassa [24].

Globaaleihin ja kansallisiin megatrendeihin sekä skenaarioihin perustuvaa tietoa tarvitaan myös osaamistarpeiden ennakointiin [25]. Tulevaisuustyöpajoissa tuotettiin osaamisalueita ja -vaatimuksia, jota tarvitaan digiosaamisen kehittämisinterventioiden suunnitteluun ja innovatiiviseen toteutukseen kehittämishankkeissa sekä laajemmin koulutussuunnittelussa, esimerkiksi sairaanhoitajan ja terveydenhoitajan opetussuunnitelmien ja koulutussisältöjen suunnittelussa sekä täydennyskoulutuksessa. Tulevaisuuden sosiaali- ja terveyspalveluissa tarvittavaa osaaminen jakautui 10 osaamisalueeseen, jotka voidaan edelleen ryhmitellä laajemmiksi osa-alueiksi. Nämä osa-alueet ovat sosiaalija terveydenhuollon ammattilaisen perusosaaminen, erikoisosaaminen sekä sosiaali- ja terveydenhuollon ammattilaisen ja teknologian ammattilaisen yhteinen osaaminen. Samanlaista jaottelua on löydettävissä Laineen [16] esittämästä digitalisaation edellyttämästä osaamisesta. Osaamisalueissa ja -vaatimuksissa oli yhtenevyyttä digitaalisen kompetenssin [15] osa-alueisiin. Sosiaali- ja terveydenhuollon ammattilaisen erikoisosaamiseen sisältyy myös tietojärjestelmien ja ohjelmistojen kehittämisosaaminen, jota tarvitaan monialaisessa tulevaisuuden sosiaali- ja terveyspalvelujen kehittämistyössä.

Skenaarioista nousivat vahvasti teemat tiedonhallinta, etäpalvelut ja biohakkerointi. Tulevaisuuden osaamisessa painotetaan näiden skenaarioiden vaatimaa osaamista kuten ohjelmien kokonaisvaltaista osaamista ja kattavaa käyttöä, tiedonhakutaitoja, asiakkaalta kerättävän tiedon tulkintaa ja hyödyntämistä, tietoisuutta sähköisistä palveluista ja työkaluista sekä sähköisten palvelujen käytön osaamista. Skenaarioissa tuli esille myös asiakaslähtöisyys ja asiakkaan vastuu. Osaamisena puolestaan kuvattiin asiakaslähtöisen palveluosaamisen, vuorovaikutus- ja verkkoviestintäosaamisen ja ohjausosaamisen vaatimuksia kuten parhaan mahdollisen tiedon ja osaamisen soveltamista, eettisyyttä, aitoa kohtaamista, asiakkaan motivointitaitoja ja erilaisten ohjausmenetelmien hallintaa.

Sosiaali- ja terveydenhuollon substanssiosaaminen ei ilmene osaamisvaatimuksista selkeästi. Ammattilaiselta edellytetään kuitenkin vahvaa ammatillista osaamista, jotta hän pystyy näkemään laajasti asiakkaan koko palvelukokonaisuuden ja osaa ottaa käyttöön asiakkaalle soveltuvat sähköiset palvelut [17]. Osaamistarkastelu edellyttää jatkotyöskentelyä. Tulevaisuustyöpajoissa tuotettiin myös aineistoa skenaarioihin johtavista teoista. Tämä aineisto antaa todennäköisesti lisätietoa myös osaamisen tarkasteluun.

Tulevaisuustyöpajoissa saatiin tietoa skenaariotyöskentelystä ja sen soveltuvuudesta kehittämistoiminnalle. Skenaariotyöskentelyllä tuotettiin alustavaa tietoa tulevaisuuden sosiaali- ja terveyspalveluista ja osaamistarpeista, osaamisen painopisteiden muutoksista, kokonaan uusista osaamisalueista ja työelämän tarvitsemista uudenlaisista osaamiskombinaatioista [ks. 25].

Työpajatyöskentely toteutettiin heterogeenisissä pienryhmissä, koska haluttiin tukea eri aloilta tulevien ammattilaisten kohtaamista ja vuoropuhelua sosiaali- ja terveydenhuollon tulevaisuuden näkymistä. Työpajan raportointivaiheessa todettiin, että heterogeenisten ryhmien muodostamat yhteiset tulevaisuuden skenaariot ja siihen liittyvät teot ja osaamiset eivät kyenneet konkreettisesti tuomaan esille eri ammattiryhmien tekoja skenaarioiden saavuttamiseksi. Pienryhmät pohtivat tehtävää laajojen kokonaisuuksien kautta pääsemättä käsiksi siihen, mikä heidän oma roolinsa skenaarion toteuttamisessa tulisi olemaan. Homogeenisemmillä ryhmillä olisi kenties ollut mahdollista tavoittaa paremmin eri ammattilaisten teot ja niihin liittyvä osaaminen. Lisäksi tukevaisuuden tarkasteluaika eli vuosi 2040 oli ilmeisesti liian kaukainen. 
Tulevaisuuden muistelu olisi edellyttänyt tietynlaista heittäytymistä tulevaisuuteen, mitä pohjustettiin asiantuntijaesityksellä työpajan alussa [20-21]. Palaute skenaariotyöskentelystä oli kuitenkin rohkaisevaa. Eri toimijoiden kohtaamisia tarvitaan palvelujen innovoinnissa. Skenaariotyöskentely on yksi tapa tarkastella tulevaisuutta ja tuottaa palveluinnovaatioita. Ennakointia tehtiin rajoja ylittäen ja osallistavan suunnittelun periaatteella [26].

Skenaariotulokset tukevat hankkeiden [18-19] tavoitteena olevan eAmmattilaisen tarvetta tulevaisuuden sosiaali- ja terveysalan työelämässä. Tulevaisuuden eAmmattilaisella on digiosaamista, joka on erityisosaamista palvelu- ja koulutustarpeiden ennakointiin, yritysyhteistyöhön, palvelujen innovointiin ja kehittämiseen sekä koulutukseen ja ohjaukseen. Osaamistarkastelu osoitti myös eri ammattilaisten osaamisen yhdistämistarpeen kehittämistyössä.

\section{Kiitokset}

Hankkeet toteutetaan Kestävää kasvua ja työtä 20142020 Suomen rakennerahasto-ohjelmassa, Vipuvoimaa EU:Ita. Kiitämme Etelä-Savon elinkeino-, liikenne- ja ympäristökeskusta hankkeiden saamasta ESRosarahoituksesta.

\section{Lähteet}

[1] Kärki T. Toiminnan digitalisaatio - miten sudenkuopat vältetään? Teoksessa Pilkahduksia tulevaisuuteen - digitalisaation ja robotisaation mahdollisuudet Valtiovarainministeriön julkaisu 10; 2017 [viitattu 28.3.2017]. Saatavilla: https://julkaisut.valtioneuvosto. fi/bitstream/handle/10024/79260/Pilkahduksia_tulevai suuteen.pdf?sequence $=1$

[2] Kullaslahti J, Karento H, Töytäri A. Opettajien digipedagoginen osaaminen FUAS-liittouman ammattikorkeakouluissa. Hämeen ammattikorkeakoulun julkaisu, HAMKin e-julkaisuja 35; 2015 [viitattu 5.1.2017]. Saatavilla: http://www.fuas.fi/fuas/Raportit/Documents/ opetajien_digipedagoginen_osaaminen.pdf
[3] Aaltonen M, Vauramo E. Sote ja Suomi 2040. Kohti taloudellisesti, sosiaalisesti ja moraalisesti kestävää Suomea. Suomen kuntaliitto; 2016 [viitattu 22.1.2017]. Saatavilla: http://www.maaseutupolitiikka.fi/files/ 3977/SOTE_ja_Suomi_2040.pdf

[4] Linturi R. Teknologiamurros 2013-2016. Esiselvitys radikaalien teknologioiden kehityksestä 2013 katsauksen jälkeen. Eduskunnan tulevaisuusvaliokunnan julkaisu 1; 2016 [viitattu 22.1.2017]. Saatavilla: https://www.eduskunta.fi/Fl/tietoaeduskunnasta/julkai sut/Documents/tuvj_1+2016.pdf

[5] Cook J, Hellström E, Hämäläinen T, Lahti V-M. Visio Suomelle. Kohti kestävää hyvinvointia. Sitra Työpaperi 31.10.2014 [viitattu 22.1.2017]. Saatavilla: http://www.sitra.fi/julkaisut/muut/Visio_Suomelle.pdf [6] Tehy ry. Tulevaisuusasiakirja. Kahdeksan megatrendiä ja Tehy. 2013 [viitattu 22.1.2017]. Saatavilla: http://docplayer.fi/3210909-Tulevaisuusasiakirjakahdeksan-megatrendia-ja-tehy.html

[7] Kiiski Kataja E. Megatrendit 2016. Tulevaisuus tapahtuu nyt. Sitra; 2016 [viitattu 22.1.2017]. Saatavilla: https://www.sitra.fi/julkaisut/Muut/Megatrendit_2016. pdf

[8] Linturi R. Teknologiamurroksesta hallinnon toimenpiteiksi. Teoksessa: Pilkahduksia tulevaisuuteen - digitalisaation ja robotisaation mahdollisuudet. Valtiovarainministeriön julkaisu 10; 2017 [viitattu 28.3.2017]. Saatavilla:

https://julkaisut.valtioneuvosto.fi/bitstream/handle/10 024/79260/Pilkahduksia_tulevaisuuteen.pdf?sequence $=1$

[9] Meristö T. Skenaariotyöskentely strategisessa johtamisessa. Miksi skenaarioita? Teoksessa Kuusi O, Bergman T, Salminen H. (toim.) Miten tutkimme tulevaisuuksia? Acta Futura Fennica no. 5, 3. uudistettu painos. Helsinki: Tulevaisuuden tutkimuksen seura; 2013.

[10] Jauhiainen A. Tieto- ja viestintätekniikka tulevaisuuden hoitotyössä. Asiantuntijaryhmän näkemys hoitotyön skenaarioista ja kvalifikaatioista vuonna 2010. Väitöskirja. Kuopion yliopiston julkaisuja E. Yhteiskuntatieteet 113. Kuopio: Kuopion yliopisto; 2004. $184 \mathrm{~s}$ 
[11] Rubin A. Skenaariotyöskentely Tulevaisuuksientutkimuksessa. 2015 [viitattu 6.1.2017). Saatavilla: https://metodix.fi/2015/01/31/skenaariotyoskentelytulevaisuuksientutkimuksessa/

[12] Rajalahti E. Terveysalan opettajien tiedonhallinnan osaamisen uudistaminen. Väitöskirja. Itä-Suomen yliopisto. Yhteiskuntatieteiden ja kauppatieteiden tiedekunta. Publications of the University of Eastern Finland, Dissertations in Social Sciences and Business Studies, no 89. Kuopio: University of Eastern Finland; 2014. $161 \mathrm{~s}$.

[13] Honkasalo R, Taipale-Lehto U. Kooste Opetushallituksen vuosina 2011-2015 tekemistä osaamistarveraporteista - muutosvoimat, osaamistarpeet ja koulutuksen kehittämisehdotukset. Teoksessa Hanhijoki I, Honkasalo R, Nyyssölä K, Savioja H, Taipale-Lehto U, Vepsäläinen J, Anttila A. Ennakoinnin koontikatsaus Osaamis- ja koulutustarpeiden ennakointituloksia. Opetushallitus. Raportit ja selvitykset 8; 2016 [viitattu 8.1.2017]. Saatavilla: http://www.oph.fi/download/ 180544_Ennakoinnin_koontikatsaus.pdf

[14] Mattila A. Taustaselvitys digitalisaatiosta johtuvista muutoksista työympäristössä, osaamisvaatimuksissa ja työn tekemisessä valituissa rooleissa. Laureaammattikorkeakoulu, Kehitysyksikkö (Opetus- ja aluekehitys); 2015 [viitattu 4.1.2017]. Saatavilla: https://ek.fi/wp-content/uploads/Taustaselvitysdigitalisaatiosta-Anssi-M.pdf

[15] Ferrari A. Digital Competence in Practice: An Analysis of Frameworks. European Commission, Joint Research Centre, JRC Technical Reports; 2012 [viitattu 6.1.2017]. Saatavilla: http://ftp.jrc.es/EURdoc/JRC68116.pdf

[16] Laine M. Digitalisaation vaatimat osaamiset valtiolla - kyselyn tulokset ja tulevat työpajat. Valtiovarainministeriö, VM/HO, Konsernitoiminnot; 2016 [viitattu 8.1.2017]. Saatavilla: http://vm.fi/documents/ 10623/3507992/Digitalisaation+vaatimat+osaamiset+va Itiolle/39f12450-b68e-4d6b-9dd9-4b8815920d57
[17] Sihvo P, Jauhiainen A, Ikonen H. Terveydenhuollon ammattilaisten laajeneva osaaminen sähköisten terveyspalvelujen kehittämisessä ja käytössä. Teoksessa Jauhiainen A, Sihvo P. (toim.) Sähköiset terveyspalvelut asiakkaiden käyttöön terveydenhuollossa - Teoriasta käytäntöön. Joensuu: Karelia-ammattikorkeakoulun julkaisuja B:33; 2014, s. 53-63.

[18] eAmmattilaiset tulevaisuuden työelämässä - Pohjois-Karjalan DigiSote -hanke. Hankesuunitelma; 2016.

[19] eAmmattilaiset tulevaisuuden työelämässä - Pohjois-Savon DigiSote -hanke. Hankesuunitelma; 2016.

[20] Rohto-tiimi/THL. Pajakäsikirja Rohto-pajan pitäjälle; 2012.

[21] Valtikka. Tulevaisuuden muistelu. 2016 [viitattu 10.10.2016].

Saatavilla: http://www.valtikka.fi/ohjaajille/menetelmapankki/pro sesseja-ja-toimintamalleja/tulevaisuuden-muistelu

[22] Stenman J, Talvela K. TUTU. Tulevaisuudentutkimuksen menetelmiä. Kymenlaakson ammattikorkeakoulun julkaisuja. Sarja A. Nro 35; 2012.

[23] Kankkunen P \& Vehviläinen-Julkunen K. Tutkimus hoitotieteessä. Helsinki: WSOYpro; 2009. 213 s.

[24] Tieto hyvinvoinnin ja uudistuvien palvelujen tukena - Sote-tieto hyötykäyttöön -strategia 2020. STM; 2014 [viitattu 27.1.2017]. Saatavilla: http://urn.fi/URN:ISBN:978-952-00-3548-8

[25] Opetusministeriö. Selvitys koulutus- ja osaamistarpeiden kehittymisestä sekä ennakoinnin tilasta ja kehittämistarpeista. Opetusministeriön työryhmämuistioita ja selvityksiä 5; 2008 [viitattu 23.10.2016]. Saatavilla: http://www.minedu.fi/OPM/Julkaisut/2008/koulutusja_osaamistarpeiden.html.

[26] Opetus- ja kulttuuriministeriö. Osaamis- ja koulutustarpeiden valtakunnallisen ennakoinnin kehittäminen. Opetus- ja kulttuuriministeriön julkaisuja 10; 2016 [viitattu 22.1.2017]. Saatavilla: http://www.minedu.fi/export/sites/default/OPM/Julkai sut/2016/liitteet/okm10.pdf?lang=fi 